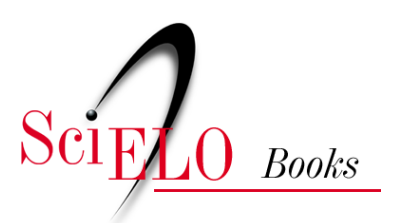

\title{
Bailes e clubes de subúrbio
}

\author{
Luciana Xavier de Oliveira
}

\section{SciELO Books / SciELO Livros / SciELO Libros}

OLIVEIRA, L. X. Bailes e clubes de subúrbio. In: A cena musical da Black Rio: estilos e mediações nos bailes soul dos anos 1970 [online]. Salvador: EDUFBA, 2018, pp. 55-72. ISBN: 978-85-2321872-0. https://doi.org/10.7476/9788523218720.0003.

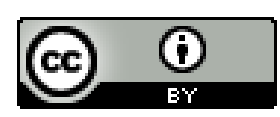

All the contents of this work, except where otherwise noted, is licensed under a Creative Commons Attribution 4.0 International license.

Todo o conteúdo deste trabalho, exceto quando houver ressalva, é publicado sob a licença $\underline{\text { Creative Commons }}$ Atribição 4.0. 


\section{Bailes e clubes de subúrbio}

Frente às múltiplas sonoridades que faziam parte da paisagem sonora do Rio de Janeiro na virada do século XIX para o XX, os gêneros musicais dançantes eram os mais popularmente difundidos, circulando entre os diferentes segmentos sociais nos diversos espaços da cidade. O lazer, a dança e as reuniões coletivas em torno da música popular, como bailes e festividades populares, ocupavam lugar central na vida social e cultural carioca. Músicas importadas da Europa e de países da América, como valsas, quadrilhas, polcas, mazurcas, tangos, habaneras e schottisches, ${ }^{1}$ marcavam presença tanto em aristocráticos salões e teatros da cidade quanto em espaços populares de divertimento, nas ruas e nas festas de família, tocadas por músicos de pouca formação musical. Essa importância estava representada na profusão de clubes sociais e de outros espaços criados especialmente para a prática da dança, muitos localizados em regiões populares desprovidas de maior infraestrutura e afastadas dos grandes centros e instituições da elite. Isso demarcava o poder da dança e dos bailes como fundamental elemento da vida social e amálgama

1 Tipo de dança campestre originária da região da Boêmia, na Alemanha, que se tornou bastante popular na Era Vitoriana, se tornando uma dança de salão semelhante à polca, mas com movimentos mais lentos. 
do estabelecimento de relações comunitárias e valores culturais periféricos já naquele período.

Herdeiros de uma lógica associativa que desde o século anterior alimentara a formação de associações mutualistas e irmandades religiosas, novos clubes se formavam a cada ano em todas as regiões com objetivos mais modestos, ligados ao prazer e ao senso de comunidade propiciado por bailes e demais festividades. (PEREIRA, 2010, p. 277)

Os bailes realizados nos clubes populares, além de despertar entusiasmo, se transformaram em espaço fundamental para a experiência social dos habitantes das regiões mais pobres da cidade, reproduzindo, à sua maneira, práticas de entretenimento da sociedade da época. Esses momentos de dança e celebração, realizados com mais assiduidade do que as festividades ligadas a feriados públicos e datas religiosas, como o Carnaval, se consolidaram como formas de lazer cotidianas tanto das elites quanto da vida dos estratos médios, fazendo também parte da rotina das populações moradoras dos bairros mais pobres. Essa maior demanda por divertimentos semanais aumentou como consequência do crescimento da cidade e da ampliação e diversificação das atividades urbanas, que ampliaram a oferta de emprego e simbolizavam uma forma de fuga diante de um cotidiano insatisfatório e mecânico do mundo do trabalho.

No final do século XIX, o Rio de Janeiro foi palco de um enorme crescimento demográfico, ocasionado pelo aumento dos fluxos migratórios do campo para as cidades, atraindo grandes massas de migrantes constituídas por escravos, ex-escravos e trabalhadores com ocupação mal definida, que eram os "excluídos" do Império. (OLIVEIRA, 2000, p. 139) Essas populações constituíram diversas comunidades, concentrando-se basicamente no centro da cidade e arredores, especialmente em cortiços e nas ainda incipientes favelas nos morros do entorno. No século XX, a cidade testemunhou uma intensa reorganização do espaço urbano motivada pelas reformas empreendidas pelo então prefeito Pereira Passos (1902-1906). A reurbanização teve como modelo as metrópoles europeias, particularmente Paris, e ocasionou 
uma reordenação do uso social do espaço urbano ao expulsar as camadas mais pobres da população para os bairros mais periféricos.

Essa reurbanização também tinha o objetivo de transformar a então capital federal no grande centro de diversões e produção artística e cultural do país (BESSA, 2008), o que era favorecido por uma rede de universidades, escolas, teatros, jornais e instituições do governo federal. Junto com a evolução das tecnologias de execução, reprodução e circulação musical, o Rio se tornou um polo de atração para a instalação de emissoras de rádio e, posteriormente, televisão, estúdios de cinema e sedes de gravadoras. O Rio, assim, se manteve não só como capital política, mas também como centro cultural do país, cujos encontros e diálogos entre diferentes grupos sociais criavam um espaço privilegiado para processos de miscigenação cultural, representando um modelo de identidade brasileira que se difundiu como o cerne da cultura nacional.

\section{O desenfreado das danças: bailes negros populares no século $\mathrm{XX}$}

Se já nas últimas décadas do século XIX, nas chácaras da Tijuca ou nos casarões de Botafogo, os senhores e senhoras promoviam saraus animados por valsas ao piano, polcas, xotes e quadrilhas - com pausas para refrescos, namoros, discursos e recitativos - na região central, especialmente na Cidade Nova, reduto da Pequena África, outras diversões ocorriam em "protoclubes" clandestinos estabelecidos em casas térreas de duas janelas e portas com rótula - os chamados “criouléus", anteriores às gafieiras. "Nesses arrasta-pés ou assustados se divertia a gente de baixa categoria social e econômica, predominando os pretos alforriados ou libertos”. (SAROLDI, 2000, p. 36, grifo do autor) Uma alternativa para uma população que não habitava em residências suficientemente grandes para a realização de festas domésticas. Assim, pequenos espaços voltados para a prática da dança e para a socialização coletiva passaram a ser criados, mediante entrada paga. Essas casas possuíam uma frequência basicamente negra e mestiça, composta por ex-escravos e descendentes que buscavam formas de divertimento e lazer mais baratas, localizadas nas redondezas dos seus locais de moradia ou em regiões centrais 
da cidade, de mais fácil acesso - especialmente em um tempo em que a circulação dos mais pobres era dificultada pela precária oferta de um transporte público. $^{2}$

A maioria dos “assustados”, que, segundo Jota Efegê (2009), eram bailes de "baixa categoria", estavam localizados na Cidade Nova. Neles, tocavam-se predominantemente os gêneros populares, como o choro, o sorongo, o arrastado, o gravanço e logo o maxixe, geralmente executados por conjuntos musicais amadores. Também alcunhados de sambas, os assustados se tornaram muito populares, porém possuíam má fama, sendo vistos como "centros de diversão onde a gente de baixo nível social dançava voluptuosamente o maxixe". (EFEGÊ, 2009, p. 23) Os assustados seriam uma etapa posterior dos criouléus do século XIX, locais populares de música e dança cujo próprio nome já denunciava a origem e composição étnica do público, criados na Bahia e trazidos para o Rio de Janeiro. Pouco tempo depois, esses espaços passaram a ser conhecidos como maxixes ou clubes de maxixe, famosos pelo "desenfreado das danças", sendo os locais de gestação do gênero popular de música e dança que logo tomaria de assalto a cidade.

Os clubes de maxixe - em sua maioria, clandestinos - eram vistos depreciativamente, considerados locais que atentavam contra a moral e os bons costumes, como denunciava Jota Efegê (2009, p. 25): “com muitos pares comprimindo-se em dança estabanada, rebolante, despreocupados da etiqueta e num agarramento antifamiliar”. Mas esse julgamento não impediu que, aos poucos, as sociedades carnavalescas e clubes recreativos - como o Clube Democráticos, Fenianos e Tenentes do Diabo, as três maiores sociedades carnavalescas da época - se rendessem ao ritmo. O maxixe era uma mistura da habanera e da polca europeias com o lundu africano, cujos movimentos eram baseados em meneios, movimentos circulares dos quadris e

2 Entre os salões da elite e os assustados, existiam outros formatos de entretenimento popular como as confeitarias e cafés, para os intelectuais e boêmios; as tascas, tabernas e quiosques frequentados majoritariamente por operários e trabalhadores informais; e as sedes dos cordões carnavalescos, voltados para a recreação e socialização de negros e mestiços pobres, como aponta Nei Lopes (2003, p. 17). Ainda havia outros formatos de entretenimento pago como os bailes de teatro, cafés-cantantes, cafés-concerto, circos e casas de chope, que já existiam na cidade desde a segunda metade do século XIX. (BESSA, 2008) 
umbigadas entre casais. Saindo do espaço dos assustados e clubes clandestinos, o maxixe chegou aos palcos dos teatros da Praça Tiradentes, cantado, dançado e tocado por grandes nomes do teatro de revista brasileiro, como Aracy Cortes e João Matos, que aprenderam os passos de dança com bailarinos populares (SAROLDI, 2000, p. 42), influenciando toda a produção musical popular da época.

Com o declínio do maxixe e o surgimento do samba, já na década de 1920, as gafieiras se espalharam pela cidade. Herdeiras dos assustados, também eram frequentadas por trabalhadores de baixo poder aquisitivo, negros e mestiços, além de malandros e prostitutas. Espécies de casas noturnas mais profissionais, nas gafieiras, eram realizados bailes com música orquestral de qualidade. A partir da década de 1960, tornaram-se um modismo e passaram a ter frequência mais eclética, incluindo pessoas da alta classe média. (LOPES, 2012, p. 162) Mas, de maneira geral, não eram espaços vistos com bons olhos pelas "boas famílias”, por conta da associação das gafieiras à marginalidade, aos vícios, à prostituição, bem como locais para concretização de enlaces extraconjugais.

Apesar das festas públicas e dos espaços das casas de dança serem espaços propícios à mescla de universos culturais, as manifestações populares e, dentro delas, o elemento negro sempre aparecem identificados com ideias de violência, criminalidade e periculosidade. (OLIVEIRA, 2000, p. 141) O negro seria uma "peça exótica" e perigosa, cujas manifestações deveriam ser combatidas ou neutralizadas pelo poder público. Mas a cultura popular sobrevivia, se esgueirando pelas brechas da cidade, demarcando espaços geográficos e simbólicos e tensionando suas dimensões em embates constantes com uma cultura de elite. ${ }^{3}$ Essa ideia era propagada tanto por autoridades

3 É digna de nota a "conquista" gradual pelos negros da festa da Igreja da Penha, até então uma celebração católica conduzida pela elite religiosa local e descendente de portugueses. Essa ocupação negra de uma das maiores festas populares da cidade recebeu atenções e reações contraditórias na imprensa, especialmente no tocante à forte repressão aos capoeiristas, que também frequentavam o evento, e ao sincretismo religioso ali praticado e mal visto na época. A história desse processo de ocupação negra da Festa da Penha se iniciou com a presença cada vez maior de baianas, que iam à festa vender seus quitutes aos frequentadores - Tia Ciata era uma delas, inclusive. Além das manifestações sincréticas que marcavam a festa, apesar da repressão, também eram realizados batuques que animavam o festejo. Aos poucos, a região do entorno da Igreja da 
policiais quanto pela imprensa e reproduzida pelos membros da classe média e elite, mentalidade que, como veremos no capítulo "Blacks sob vigilância", permenceu sendo reproduzida em relação aos bailes soul dos anos 1970. Mas, da mesma forma, não impediu o sucesso desses eventos entre as classes trabalhadoras mais pobres, cujos modos de lazer e fruição musical estruturaram formatos de entretenimento popular ao longo do século XX.

Essa construção de espaços geográficos e simbólicos demarcados por uma produção cultural negra e periférica não se dava de forma harmônica e pacífica. Havia tensões e conflitos que revelavam um processo de distensão e, ao mesmo tempo, de mesclas inconclusas entre uma cultura de elite e uma cultura popular, sendo que a primeira passou, paulatinamente, a beber da segunda. Esses trânsitos e diálogos se tornaram uma marca da identidade carioca e também da cultura nacional, complexificando relações raciais, questões de gosto e construções de valor na cidade. Sobre esse processo, aproprio-me da reflexão de Roberto Moura (2000, p. 153): "Assim, se um Rio de Janeiro era inventado ideológica e urbanisticamente pelas elites a partir de suas referências europeias, era reinventado pelo convívio daqueles com o povo apresentado por sua música”. Uma música popular que consolidava, transversalmente, uma cidadania marginalizada, constituída a partir de novas manifestações culturais que se configuravam durante a modernização da então capital federal.

\section{Uma nova cidade: desenvolvimento suburbano}

A Cidade Nova, região onde floresceram os primeiros momentos de uma cultura periférica de entretenimento carioca, foi irregularmente povoada após a expulsão da massa popular pelas obras de Pereira Passos. Essa "nova cidade" começa a se definir nas margens da área mais nobre e comercial do centro, "subindo pela Rua do Sabão até os arredores do Campo de Santana e da Praça Onze de Julho”. (MOURA, 2000, p. 122) A Cidade Nova também chegou até as favelas espalhadas pelos morros e encostas dos bairros da Saúde,

Penha se tornou ponto de encontro de sambistas famosos, como Donga e Pixinguinha, que, durante a festa, podiam mostrar suas composições e divulgar sua arte. 
Estácio e Mangueira, atingindo as circunvizinhanças dos pequenos núcleos de classe média no subúrbio. Um ponto importante dessa área foi a zona da Pequena África, que se estendia da região portuária à Praça XI, considerada o local do surgimento do samba. Foi na Cidade Nova que se estabelece, pela primeira vez, um espaço popular na cidade, mediante movimentos de ocupação e migração. O surgimento de novos padrões para a cultura urbana carioca tensionava noções de progresso e atraso, nacional e estrangeiro, autêntico e cooptado, gerando uma série de conflitos em torno das diferentes apreensões do que seria legitimamente popular. As festas populares e a música se tornaram um meio condutor dessa interpenetração, que também chegava aos subúrbios ainda em formação.

Naquele tempo, os subúrbios basicamente englobavam os bairros da Gamboa, Saúde, Penha e proximidades. Em uma nomenclatura mais antiga, o município do Rio de Janeiro era dividido em três zonas: a Urbana, que incluía o atual centro da cidade, a Zona Sul, dos bairros mais antigos, como Glória, Catete e Botafogo, e a região da Tijuca e arredores, áreas mais nobre ocupada por casarões e chácaras; a Zona Suburbana, que reunia os bairros da hoje chamada Zona Norte e bairros centrais mais pobres; e a Rural, depois denominada Zona Oeste, abrangendo toda a metade ocidental da cidade. Na linguagem popular, atualmente, o subúrbio engloba a Zona Norte, trechos da Zona Oeste e parte da antiga Zona Urbana, região central. Coloquialmente, a ideia de subúrbio assume um sentido de periferia, cujas conotações pejorativas possuem estreita relação com questões de classe e raça. Esta área, historicamente, congregava uma classe trabalhadora, mas também subempregada ou desempregada, mal provida de serviços, infraestrutura e opções de lazer. O subúrbio, assim, passou a ser visto como sinônimo de pobreza, inferioridade e atraso, a partir de uma ótica discriminatória.

Da mesma forma que a recente difusão do termo 'urbano', como sinônimo de cosmopolita e universal, é uma criação dos 'modernos' de hoje, a generalização da ideia de subúrbio como lugar carente, sem ordem nem conforto, habitado por pessoas pobres, sem educação ou refinamento, parece ser uma criação das antigas elites cariocas. (LOPES, 2012, p. 9) 
Essa separação da cidade em diferentes zonas também tinha relação com a proximidade de cada área para com o litoral. Quanto mais próximos do mar, mais importantes e valorizados, e esses bairros serviam, preferencialmente, como habitação para as classes mais altas e para a instalação de prédios públicos e centros administrativos e financeiros. Para Lopes (2012), a proposta de conectar o litoral das elites ao centro administrativo da cidade, especialmente durante a gestão do Pereira Passos, foi a razão da expulsão da população mais pobre do centro da cidade. Com a instalação de fábricas em áreas mais distantes do centro e, posteriormente, com a construção da linha férrea, essa população começou a se deslocar para os subúrbios, se concentrando ao longo da malha ferroviária. Desse modo, a expressão "subúrbio", às vezes usada no plural, passou a denominar toda a região residencial e industrial constituída entre a Serra do Engenho Novo, o Morro do Telégrafo, na Mangueira, e o morro do Retiro, Maciço dos Coqueiros/Retiro, em Realengo, acompanhando as linhas férreas que corriam em direção ao interior. (BERNARDES; SOARES, 1995, p. 98) A ocupação da Zona Suburbana carioca, portanto, pode ser atribuída às aglomerações formadas em função da atividade portuária/industrial, ao loteamento de fazendas para estabelecimento de moradias e aos agrupamentos habitacionais populares construídos ao longo das principais vias de acesso, como primeiramente as ferrovias e depois as rodovias. (PINHO, 2006, p. 175)

Nos anos 1960, a paisagem suburbana assumia um aspecto desordenado, com pouca infraestrutura e parco acesso a serviços básicos, mas acompanhada por uma urbanização acelerada e um aumento demográfico formado por populações de baixo poder aquisitivo. Essas pessoas ainda dependiam de longos deslocamentos por meio do transporte ferroviário e rodoviário para o centro e Zona Sul, onde se localizavam a maior parte dos postos de trabalho. A necessidade de fontes de consumo e serviços mais próximas acabou gerando subcentros comerciais em tradicionais polos suburbanos, como Madureira, Méier, Tijuca, Bangu e Campo Grande. Para Fernandes (2011), a palavra "subúrbio", na acepção mais moderna, não se referia, pois, à periferia da cidade, mas sim a esses bairros populares ferroviários e de intenso comércio, situados dentro do território da área urbana. Os bairros de Barra de Guaratiba, Barra da Tijuca, Grumari e Recreio dos Bandeirantes são pertencentes 
à Zona Oeste, mas, por sua proximidade ao litoral e por serem considerados bairros de elite por conta da história da sua ocupação recente, destoam dos demais bairros da região. Assim, na linguagem corrente e na imprensa, esses bairros passaram a ser incluídos na Zona Sul.

Já na administração de Carlos Lacerda (1961-1965), o Rio de Janeiro, agora ex-capital federal e atual capital do estado da Guanabara, possuía a mais elevada concentração demográfica do país (2.824 habitantes por km²), com uma população de mais de 3 milhões de habitantes, localizados, sobretudo, nas áreas urbana e suburbana. ${ }^{4}$ (MOTTA, 2000, p. 82) Apesar da perda de espaço em nível nacional, o parque industrial carioca era o segundo do país, com um claro predomínio de ramos ligados aos bens de consumo direto, como produtos alimentares, têxteis, vestuário e calçados. A transferência das atividades industriais para os subúrbios demandava a construção de grandes conjuntos habitacionais de apartamentos para trabalhadores e suas famílias. (MOTTA, 2000, p. 88)

Nesse período, o Rio passou por novas mudanças no espaço urbano. O governo Lacerda empreendeu projetos polêmicos, como a remoção das favelas da Zona Sul e a construção de conjuntos populares na Zona Oeste. Uma das marcas da ocupação do Rio de Janeiro são as muitas favelas instaladas nos morros localizados no coração da Zona Sul, e essas áreas nobres interessam ao capital imobiliário e à expansão da construção civil, favorecendo investimentos lucrativos e especulação. Havia também uma pressão por parte das classes médias em nome de um "progresso" e "bem-estar", e a remoção de favelas se tornou uma demanda de ordem pública.

A ideia de deslocar populações de baixa renda para longe das partes centrais da cidade não era nova, mas esse processo foi acompanhado por um decisivo alargamento da malha viária. A abertura de túneis - como o Santa Bárbara, ligando o bairro do Catumbi a Laranjeiras, e o túnel Rebouças, conectando o Rio Comprido à Lagoa -, a construção de viadutos e o aumento

4 Sua densidade econômica era igualmente expressiva, já que ocupava o segundo lugar no ranking dos estados da federação, vindo atrás apenas de São Paulo. Essa densidade se refletia na renda per capita do estado, a mais alta do país, com quase o triplo da média nacional. (MOTTA, 2000, p. 82-83) 
da oferta de transporte rodoviário contribuíram para uma ligação mais efetiva entre Zonas Norte e Sul. "O rodoviarismo resultante do modelo desenvolvimentista adotado pelo país exigia vias expressas mais rápidas”. (MOTTA, 2000, p. 89) O crescimento da área metropolitana carioca acabou sendo ocasionado muito mais pela própria expansão dos subúrbios e também da Zona Rural - que inclui desde Deodoro até Santa Cruz, passando por Campo dos Afonsos até Sepetiba -, do que pela expansão da parte central. Isso foi motivado pelo crescimento populacional nessas áreas mais populares, causado pelo intenso êxodo rural e pelo crescimento desordenado da população. Hoje, a ideia de subúrbio que integra o domínio público do Rio de Janeiro, mais do que uma denominação geográfica que compreende o norte da cidade, englobando bairros cortados pelas linhas férreas da Central do Brasil e da Leopoldina, se refere à sua oposição em relação à Zona Sul enquanto seu status social, sinônimo de pobreza, provincianismo e anacronismo. Para Souza (2003, p. 99), o subúrbio também representa um espaço de encontro entre o urbano e o rural, um local de idealização de relações pessoais e comunitárias mais fortes, bem como de preservação das tradições. É possivel, pois, pensar em uma identidade suburbana cujos atributos mais característicos podem ser articulados a uma maior comunicação interpessoal, laços de solidariedade mais coesos na proximidade das relações de vizinhança e amizade. A vida social comunitária no subúrbio, pois, seria idealizada a partir de uma maior qualidade e intensidade das relações sociais. (TROTTA; OLIVEIRA, 2015, p. 109)

Aos poucos, no lugar de estereótipos negativos ligados à ingenuidade, atraso e inferioridade, o subúrbio começou a ser percebido como fonte de novas linguagens, estéticas e modas, definindo outras estratégias de sobrevivência cultural e hábitos de consumo simbólico em circuitos alternativos de entretenimento, especialmente a partir do estabelecimento de clubes e de outros espaços voltados para o lazer e para a difusão de uma cultura popular massiva.

\section{Clubes e bailes de salão}

Consequência direta da instalação na cidade de um número expressivo de fábricas, os clubes tiveram um grande crescimento no começo do século XX, em vários bairros. Como espaços privilegiados para a prática da dança e 
atividades de entretenimento, os clubes passaram a marcar a vida social desde vizinhanças elegantes, como Botafogo e Catete, a subúrbios e bairros proletários, como Méier, Bangu e Madureira. A diferença residia no estereótipo da violência que era atribuído aos bailes suburbanos, eventos supostamente marcados por brigas, disputas e outras atividades tidas como imorais, relacionadas à prática de danças vistas como "lascivas". Mas, na verdade, os clubes suburbanos correspondiam a um esforço empreendido por seus sócios na criação de espaços de lazer e sociabilidade mais "respeitáveis", voltados para as famílias pertencentes a uma nova classe média baixa e estratos proletários que se desenvolviam e habitavam as redondezas.

Os clubes sociais populares surgem influenciados pelos sport clubs ingleses, criados no Rio de Janeiro após a instalação de companhias britânicas na cidade como a Light and Power, Bank of London, Leopoldina Railway, Western Telegraph, Rio de Janeiro Traction, entre outras. Os clubes abriam espaço para círculos sociais cujos membros e sócios, em sua maioria compostos por ingleses e seus familiares, se reuniam para atividades de lazer e convivência e também para a prática de esportes. O Rio Cricket, por exemplo, fundado em Niterói em 1897, era um clube de inverno voltado para a prática do cricket, onde trabalhadores britânicos confraternizavam e mantinham o elo com suas comunidades de origem. (LOPES, 2012, p. 103) Outros clubes voltados para o yatching e, principalmente, para ofootball também foram fundados nessa mesma época na Zona Sul do Rio, como o Botafogo, em 1894; o Flamengo, em 1895; e o Fluminense, em 1902.

Os clubes passaram a representar um espaço de convivência das chamadas "boas famílias" das elites, que se contrapunham aos supostos "maus elementos", cujos espaços eram as ruas e as zonas mais pobres. Com a expansão dos subúrbios, diante do aumento gradativo do poder aquisitivo de seus moradores, começam a ser criados clubes também na região suburbana da cidade. Em 1904, foi fundado o Bangu Atlético Clube por funcionários ingleses da Companhia Progresso Industrial do Brasil, a Fábrica Bangu. O bairro, por ter abrigado ao longo de sua história uma série de indústrias, cresceu diante da chegada de grandes massas de trabalhadores e se tornou um dos principais polos da Zona Oeste. No entanto, o Bangu Atlético Clube tinha um diferencial. Ao contrário dos outros clubes ingleses de futebol, a diretoria não se 
opunha à participação de negros na equipe e entre seus sócios, inclusive consagrando a instituição como uma opositora ao racismo no futebol. Outro clube da região, o Cassino Bangu, também ficou famoso por congregar a Sociedade Musical Progresso de Bangu, sendo visto como uma das poucas opções de lazer da população local. Em 1915, era fundado o Tijuca Tênis Clube, ${ }^{5}$ que se consolidou como opção de lazer para as famílias da região do Andaraí Pequeno e de outros bairros próximos da Zona Norte. Anos depois, com a mesma motivação, foi criada a Associação Atlética Vila Isabel, em 1950, por um grupo de militares de altas patentes. Um ano depois, foi criado o Renascença Clube, por uma classe média negra da Zona Norte, sendo primeiramente instalado no bairro do Lins, depois transferido para o Andaraí, com uma motivação diferente, voltada para a conscientização e valorização racial, como será visto no capítulo "O movimento".

Os clubes ofereciam um espaço mais adequado às "boas” famílias, cujos membros não deveriam frequentar gafieiras, dancings ou boates, por exemplos, tidos como locais frequentados apenas por classes mais baixas, voltados para um público "menos familiar", considerados locais favoráveis à prática da prostituição e de enlaces extraconjugais. Essa noção de preservação da moral e dos bons costumes advinda das elites passou a ser também reproduzida por estratos mais baixos de uma classe média proletária que buscava outras formas de entretenimento de acordo com seus status sociais nos pequenos núcleos de urbanização dos subúrbios. Os clubes suburbanos também se voltavam para a realização de festas e eventos sociais dançantes, geralmente voltados para a prática da dança em pares, ao som de gêneros musicais como o samba, a rumba e o bolero, suprindo uma necessidade de lazer e diversão mais moralizada. Os bailes eram de alta qualidade, animados por orquestras e conjuntos famosos e se tornaram eventos semanais frequentes que ganharam dimensão ainda maior com a difusão de outros gêneros musicais internacionais por meio do rádio e do crescimento da indústria fonográfica no Brasil.

5 Instituição emblemática por ter inaugurado a primeira piscina comunitária da Zona Norte carioca. Um fato histórico e social importante, levando-se em consideração a distância do mar, de acesso difícil, em uma época em que a comunicação entre as várias partes de uma cidade era bastante complicada, especialmente tendo em vista a pequena quantidade de vias de tráfego, um grande número de morros e pouquíssimos túneis. 
Lima Barreto afirmava, em crônica publicada no jornal Gazeta no ano de 1922, que os clubes do "pequeno povo", por não conhecerem danças norte-americanas como o foxtrote e o shimmy, populares nos salões das elites, organizavam seus bailes animados por gêneros populares "ultrapassados", ao som de pianos ou charangas. No entanto, mesmo nos bailes populares, sonoridades estrangeiras faziam sucesso ao lado de gêneros musicais brasileiros mais tradicionais. Um exemplo eram os bailes realizados em um famoso clube fundado por trabalhadores em Bangu, chamado O Prazer das Morenas. Segundo matéria "Prazer das Morenas de Bangu”, publicada no Jornal do Brasil, em 12 de janeiro de 1927, os bailes desse clube eram tanto um lugar da tradição (maxixes, sambas) quanto da modernidade, representada pelo jazz e foxtrote americano: “A barulhenta jazz-band 'Eu Não Disse?' não deu um minuto de trégua aos dançarinos, com os seus variadíssimos sambas e foxtrotes ultra modernos".

A tradição da realização de bailes de salões em clubes, agremiações ou associações de diversas origens é recorrente em todo o mundo, especialmente na América Latina, e se estabelece como hábito cultural decorrente da urbanização e do desenvolvimento da cultura popular massiva. O que chama a atenção para o estudo dos bailes cariocas suburbanos é a condição de serem marcados por uma dinâmica da contemporaneidade (PEREIRA, 2010, p. 280 ), concretizando práticas diferenciadas de consumo e valor social. Ao se aproximarem de um formato de entretenimento próximo ao proposto pelas elites, sem abandonar por completo tradições populares, acabaram por definir um novo modelo para o entretenimento popular na cidade, intermediado por hibridizações musicais com produtos internacionais. A diferença das instituições modernas ocidentais em relação às formas distintas de ordem social implicam novas dinâmicas, intervindo em hábitos e costumes tradicionais, modificando radicalmente a vida cotidiana ao afetar aspectos mais pessoais da experiência. E essa vivência da modernidade tardia, segundo Giddens (2002, p. 9), foi canalizada pelos meios de comunicação, influenciando tanto as alteridades quanto a organização das relações sociais.

A instituição dos clubes e agremiações foi transposta para as práticas populares, constituindo um longo e impalpável processo de comunicação entre diferentes grupos sociais, que auxiliaram a definir algumas das imagens 
associadas hoje à cultura carioca e, por conseguinte, à brasileira, marcada pelos diálogos e pelos intercâmbios de costumes e tradições ao longo do tempo. As associações recreativas se consolidaram como espaços de entretenimento cotidiano popular, visto que não havia grande oferta de espaços públicos de lazer nas áreas suburbanas. Nesse cenário, a música popular era um meio privilegiado de diversão (PEREIRA, 2010, p. 283), em que ritmo, dança e festa assumiam uma centralidade fundamental na experiência de sociabilidade das classes populares. Diante da necessidade de estabelecer novas redes de contato e vínculos comunitários, recriando tradições e absorvendo influências de outras culturas e grupos sociais, os bailes se apresentaram como filtros de uma cultura global e estabeleciam territórios significativos para a organização de suas proximidades e diferenças, importante em um contexto urbano marcado pela desigualdade social e racial.

As peculiaridades da experiência colonial latino-americana, a expansão demográfica, a maior participação popular na dinâmica urbana e a difusão do capitalismo contribuíram para a formação de novos estilos de vida, ainda no final do século XIX, o que implicou a adoção de formas aburguesadas de desfrutar atrações urbanas em modos de divertimento barato. "Certamente por esta razão, o dia não bastava, despertando-se desde então o gosto carioca pela vida noturna, em casa, no teatro ou no sereno da rua”. (LOPES, 2000, p. 10) Assim, a cultura do Rio se formou a partir de invenções populares e elitistas, do confronto ou fusão desses dois âmbitos, da cópia do modelo externo e da adaptação dessas influências na criação de linguagens e produtos originais, representando a vocação cosmopolita popular da vida carioca.

Consagrando-se como centro da vida política e cultural da nação, especialmente a partir da República, além de polo financeiro, o Rio de Janeiro projetou a autoimagem nacional, exercendo um poder difusor de modas, costumes e produtos culturais, também repercutindo os efeitos de seus movimentos sociais pelo resto da nação. (OLIVEIRA, 2000) Até os anos 1960, a cidade se manteve não só como capital política, mas também como espaço privilegiado de processos de hibridização e miscigenação cultural, representando um modelo de brasilidade que se difundiu como aquele que caracterizaria a cultura oficial nacional brasileira. 
O Rio de Janeiro, enquanto capital da República, representou a ponta estratégica da modernização do final do século XIX e início do século XX. A cidade possuía uma sólida estrutura de bens culturais, representados por teatros, cinemas, museus e bibliotecas, somados a uma rede de instituições educacionais, representada por universidades, centros e institutos de pesquisa, além de ser onde estavam localizados os maiores canais de TV, emissoras de rádio, estúdios cinematográficos e gravadoras. Mesmo assim, manifestações culturais populares não desaparecem e fortaleceram-se, justamente pelos contatos com uma cultura que vinha de fora. O samba foi o exemplo máximo que representou o ponto de encontro entre intelectuais, jornalistas e compositores populares, marcando o momento de embaralhamento de fronteiras entre brancos e negros, ricos e pobres, tradição e modernidade, cultura de elite e cultura popular. A adaptação de expressões locais se mesclava às estrangeiras, comprovando a capacidade da cultura popular de assimilar o externo. O surgimento de novos padrões populares tensionava, pois, noções de progresso e atraso, nacional e estrangeiro, autêntico e cooptado, gerando uma série de desvios e vetores de interpenetração.

[...] o tempo provaria que nem sempre as ideias dominantes são as ideias da classe dominante. A debilidade do projeto afrancesado das elites seria minada por um movimento subterrâneo e potente de abertura para valores miscigenados de cultura. Não é o caso de celebrá-los como valores de 'resistência' das classes dominadas, ou de alternativamente acusar a apropriação indevida de elementos 'autênticos' pelo poder. O fato é que só essa produção dialogizada de elementos interétnicos e interclasses foi capaz de lançar um projeto de identidade possível de ser aceito por amplos setores da população como sendo 'a nossa cara'. (LOPES, 2000, p. 28)

Os bailes dialogavam com diversos signos de distinção, que demarcavam territórios articulados a diferentes formas de estilo de vida e representações. O que estava - e ainda está - em jogo nas pistas de dança é a afirmação de identidades e da sua legitimidade, cujos elementos, valores e símbolos encenam uma estética cosmopolita e moderna, amplamente moldada pelo consumo musical massivo. Esses aspectos determinaram, assim, as bases da 
hegemonia de um modelo de entretenimento pautado pelo popular. Os bailes, em suas diversas manifestações, se instituíram como territórios simbólicos para o exercício de sociabilidades, dentro de um formato comunitário e criativo. A partir desses espaços identitários, é possível refletir sobre estilos e modos urbanos de vida, pois, como afirma Sevilla (2005, p. 184), os bailes expressavam, através do corpo (individual e coletivo), as dinâmicas sociais das cidades modernas. Quanto ao momento do baile, também por sua regularidade de realização e frequência, o que o diferencia das festas populares mais sazonais, por exemplo, reforça vínculos, marcas e códigos sociais, revelando novas linguagens e estilos, percebidos de maneiras distintas pelo restante da sociedade, mas que se tornam parte integrante das identidades dos participantes. Para Rocha (2012, p. 61), os bailes eram espaços de criação e manutenção das sociabilidades do grupo, "uma prática onde os agentes sociais podem reconhecer e reafirmar seus valores" e se convertem em local privilegiado de distinção, legitimando determinadas visões de mundo.

O desenvolvimento urbano a partir da Revolução Industrial gerou o surgimento de novas ofertas culturais nas cidades. Ampliaram-se as alternativas de divertimentos públicos e, aos poucos, o Rio de Janeiro testemunhava um aumento da demanda por eventos festivos por seus habitantes, pela gente comum que passava a celebrar sem comemorar em festas privadas, independentemente de qualquer outra razão que não fosse a do puro entretenimento e lazer. O desfrute coletivo da música e da dança, aos poucos, gerou os bailes de salão, tanto em bairros de elite quanto em regiões mais pobres. Dos assustados às gafieiras, chegando aos clubes suburbanos, a cidade presenciou uma crescente efervescência gerada especialmente por esse tipo de atividade. Se, em uma visão mais superficial, historicamente, os bailes formassem parte do patrimônio cultural das elites, como sinônimo de ricas festas, luxos e abundâncias, distinguindo a alta sociedade da "ralé", por conseguinte, as classes populares se apropriaram dessa prática para posteriormente construir seus próprios espaços de lazer. Primeiro, através de festas familiares ou comunitárias, para depois constituírem suas próprias redes de entretenimento, especialmente diante do desenvolvimento de novas tecnologias de comunicação, como a expansão do rádio e do mercado do disco, facilitando o acesso a 
produtos culturais internacionais, possibilitando hibridizações e difundindo novas modas e práticas de sociabilidade.

O baile, através da associação de sensações, escutas, performances e discursos, representa o tempo da emoção e do êxtase, que é efêmero. Mas implica uma experiência de aproximação e contato com o outro, durante um momento de partilha de vivências e trocas que podem fixar uma série de códigos sociais. A compreensão da dimensão dos bailes fornece uma via de acesso para a compreensão dos valores e relações sociais, pois eles representam um momento excepcional dentro da vida cotidiana, dramatizando diversas representações da realidade social, deixando em suspensão possíveis conflitos e desigualdades. Os bailes populares, ao absorverem a dimensão da festa, trazem o extraordinário para o cotidiano, catalisando com mais frequência os encontros e experiências performáticas e identitárias. Esses divertimentos públicos são fundamentais na manutenção da solidariedade grupal, incentivando a aproximação de indivíduos ao colocar as "relações sociais em estado de efervescência”. (COSTA, 2009, p. 70)

Durante a "interrupção" da vida social ordinária e do regime de trabalho, nos momentos efêmeros da festa, é possível realizar uma espécie de "renovação moral” que fortalece os laços de solidariedade grupal. (COSTA, 2009, p. 71) O baile marca uma atitude de transgressão perante a vida social, representando uma desagregação de uma ordem estabelecida, tanto através de excessos quanto por meio de contatos que recriam a realidade e têm o poder de revigorar a própria estrutura social.

A ruptura proporcionada pela festa [...] reside na descoberta dos sujeitos participantes da possibilidade de 'liberarem-se de si mesmos' e de enfrentar o mundo das regras de conduta e procedimento com a instauração de um tempo 'sem leis, nem forma'. Neste ponto, o sujeito da festa opera uma 'superação' da normalidade, de modo a identificar-se com um personagem imaginário numa comunidade imaginária, que exercita mecanismos que abalam as instituições normativas da sociedade. (COSTA, 2009, p. 71)

Do nosso ponto de vista, os bailes populares conseguiram reunir uma relevância cultural singular no tecido social carioca ao conjugar música e 
corpo, lúdico e erótico, lazer e exercício, o corpo individual e corpo coletivo. Além de funcionarem como um alívio contra as tensões originadas do cotidiano, especialmente em contextos de opressão e segregação, eles permitiam a criação de fortes vínculos identitários. Essas reflexões nos permitem compreender como os bailes soul dos anos 1970, em suas diferentes dimensões, imprimiram poderosos signos de distinção, na medida em que o corpo, a performance e o estilo manifestavam gostos e preferências de consumo, expressando a inscrição em variados tipos de pertencimento e afiliações sociais. Essas identidades concretizadas nas pistas de dança produziam estereótipos contrastantes, como jovem-velho, rico-pobre, negro-branco, nacional-global, mas também embaralhavam essas categorias ao possibilitar novos exercícios de diferenciação, que poderiam ser negados ou neutralizados em outras esferas. É dessa forma que os bailes funcionavam como veículo de expressão de associações sociais e se constituíam como territórios simbólicos.

As festas black estabeleciam redes de consumo, lazer e entretenimento guiadas pela música, que vinculavam a ocupação de espaços à proposição de novas representações socioculturais, que também eram políticas. Essas ações eram articuladas a práticas de consumo alternativas e marginais que, ao mesmo tempo, flertavam com uma cultura mainstream. Era por meio da dança e do estilo que os corpos comunicavam e se tornavam instrumentos de mediação e afirmação da diferença, reconfigurando uma cultura popular e negra. $\mathrm{O}$ consumo massivo associado a essas experiências de negritude incorporava uma possibilidade de representação da diferença cultural na qual os gêneros musicais assumiam uma função social e um papel simbólico em processos de disputas pelo poder. É Martín-Barbero (2008, p. 314) que diz que os gêneros massivos podem agir como uma espécie de mediadores sociais no interior da cultura popular massiva, em que atuam como modelos dinâmicos de negociação e estruturas de caráter social e ideológico, cujos códigos e convenções reconhecíveis por seus consumidores funcionam como portas de entrada para a produção de sentido e de identidades. Assim, a circulação da música na cena da Black Rio confirmava os bailes como expressões simbólicas da trama social, mas também como exercícios de novas expectivas, experiências e subjetividades, como discutirei nos próximos capítulos. 